\title{
Behaviour of RC Buildings with Single and Double Outriggers under Seismic Response
}

\author{
Waleed Abdallah Ali
}

\begin{abstract}
Today, tall structures are inescapable in urban communities. Along these lines, the structure requires a production system which can effectively participate in resisting the applied wind and earthquake loads. Among the available lateral load resisting systems, outrigger, as rigid horizontal elements connect shear walls to exterior columns is the most commonly used to enhance tall structures performance under lateral forces. A series of dynamic response spectrum (RS) analyses devoted to assess the seismic response behavior of R.C tall buildings with central core wall having outrigger system. Several models with and without outrigger systems were considered in the analysis in order to investigate the ideal position and the number of outriggers. The developed building models have either one or two outriggers. Structural software package ETABS was used to develop the considered herein different configurations of the building models as well as performing the dynamic analysis. The performance of the considered different configurations was investigated in terms of displacement and inter-storey drift peak profiles. Sensitivity to the position of outrigger on the induced wall bending moment was also explored comparing the responses of the different configurations. The results of the performed study can provide structural designers with the optimum location of a single or either double outrigger in order to minimize the induced seismic response during the initial stage of the outrigger system design process. The optimum locations of outriggers are quarter height of the building in case of using single outrigger and at quarter and three quarters of the building in case of using double outrigger in order to minimize the induced moment values on the core and columns
\end{abstract}

Keywords : R.C Tall buildings, Outrigger, seismic responses, RS analysis, ETABS.

\section{INTRODUCTION}

In high-rise buildings, serviceability and safety have been major issues due to lateral displacements caused by lateral loads, such as wind or earthquake loads, which increase as the building height increases. Typical structural systems like frames and coupled shear wall systems which used to control the lateral displacements of tall buildings are often unsuitable to satisfy lateral drift and displacement limit conditions as the height of the building increases. Therefore, new structural systems such as outrigger system are used to control the induced seismic responses of high-rise buildings. The outriggers are horizontal elements like deep beam or belt

Revised Manuscript Received on February 05, 2020.

* Correspondence Author

Waleed Abdallah Ali*, Assistant Prof. Faculty of Engineering, Civil

Department, Helwan University, Cairo, Egypt. Email: Waleed_abdallah@m-eng.helwan.edu.eg

(C) The Authors. Published by Blue Eyes Intelligence Engineering and Sciences Publication (BEIESP). This is an open access article under the CC BY-NC-ND license (http://creativecommons.org/licenses/by-nc-nd/4.0/) truss connecting the core wall to the exterior columns at one or more levels throughout the height of the building as shown in Fig.1 Outrigger should be placed at locations where the diagonal bracing will not interfere with the building's function. They are generally located at the mechanical equipment floors in order not to hinder the use of normal floors. Kamath et. al, [1] studied the behavior of a 40 storey R.C building with and without outrigger system at different location through varying outrigger height ratio with varied relative stiffness values. The height ratio refers to the height where the outrigger is placed to the total height of the building. The effect of introducing the outrigger structural systems at different levels for controlling the top displacements as well as reducing the inter storey drifts has also been studied. The behavior of a 30 storey RC building with an outrigger system under wind and earthquake loads has been investigated by [2]. The optimized location and efficiency of the outrigger system have also been investigated under the applied lateral loads. M.R. Suresh, and S. Badami [3] studied the influence of using different structural systems on the dynamic behavior of RC building with different storey heights under both vertical and lateral loads. These used lateral systems in the study include rigid frame, shear wall/central core, wall-frame interaction, and outrigger. A Mulla, and B.N Srinivas [4] studied the behavior of the outrigger in regular and irregular structures. They studied two models of 20 storey R.C building structures with and without outrigger. The effect of the size of the outrigger members on the induced story displacement has been studied. The effect of concrete and steel outriggers on the lateral displacement of the building's storey has been studied as well. D.J. Prasad, and S. Kumar [5] studied a 30-storey RC building with vertical irregularity. Three different analyzed models, building with outrigger only, belt truss only and outrigger with belt truss in which their position remains constant in all the models. K. Venkatesh, and B. Ajitha [6] studied the behavior of outrigger, outrigger location optimization and the efficiency of used three outriggers on a 20 story office RC building. C. Patel, and K. Kuldeep [7] studied the influence of using two different positions of shear walls, one position at the center and the other one at the corner of the building with different positions of outrigger and belt truss on 32 storey RC building. V. Dongre, and V. Garg, [8] performed a comparative study between virtual and conventional outrigger systems to investigate their effects in resisting lateral loads using RC building of $30 \mathrm{~m}$ heights. The study focuses on analyzing the structural components of outrigger system, Outrigger truss, Belt truss, stiff core and the load transferring mechanism. Most of the above cited research work focus on the effect of the use of a single outrigger on the induced response of high rise buildings under seismic loads. 
The current research work investigates the effect of use either a single or double outrigger system on the dynamic behavior of tall buildings in order to provide structural designers with the optimum locations of outriggers.

\section{MODELING AND IDEALIZATION}

\section{A. Building Description}

In order to seismically investigate the behavior of buildings with and without outrigger, a 20-story residential RC building with a typical floor height of 3m located in Cairo is considered in this current study as shown in Fig. 2. Different building models have been developed in order to meet the cases considered in the study, building with core only, buildings with one outrigger system at different levels, buildings with one fixed outrigger system at the top of the building in addition to another with varying levels and buildings with two outriggers system at different levels. Due to the symmetrical view of the considered model, the effect of torsional response has been avoided. The building's layout is a square shape $(30 \mathrm{~m} \times 30 \mathrm{~m})$ divided into equal 5 bays on each side as well (see Fig. 3 ). The strength of the materials used to perform the structural design is $30 \mathrm{MPa}$ and $360 \mathrm{MPa}$ for concrete and steel reinforcement respectively. Modulus of elasticity of concrete $21 \mathrm{GPa}$ was considered and Poisson's ratio was assigned as $0 \cdot 2$. The designed column sections are $800 \times 800 \mathrm{~mm}$ for corner columns, 400x1800 mm for edge columns and $1250 \times 1250 \mathrm{~mm}$ for central columns. The columns dimensions are reduced as the height of building increases each three floors. The central $6 \times 6 \mathrm{~m}$ massive core with concrete walls of $300 \mathrm{~mm}$ thickness is symmetrical in both longitudinal and transverse directions and it is connected to columns via one-storey high belt truss consisting of in-floor braces and vertical trusses. Hence, this hybrid dual system, composed of bracing, outriggers and belts, provides lateral stability, redistribute loads if some members are damaged by unforeseen circumstances and maximizes the spaces inside the building. The slab thickness was $200 \mathrm{~mm}$ supported on 200 x $500 \mathrm{~mm}$ concrete beams. The Outrigger sections are box sections (250x250x12) mm with steel Grade 37-240 Mpa. The considered loads were $2 \mathrm{kN} / \mathrm{m} 2$ for live loads, $2 \mathrm{kN} / \mathrm{m} 2$ for floor cover and $16 \mathrm{kN} /$ m3 for wall density according to Egyptian code (ECP-201, 203).

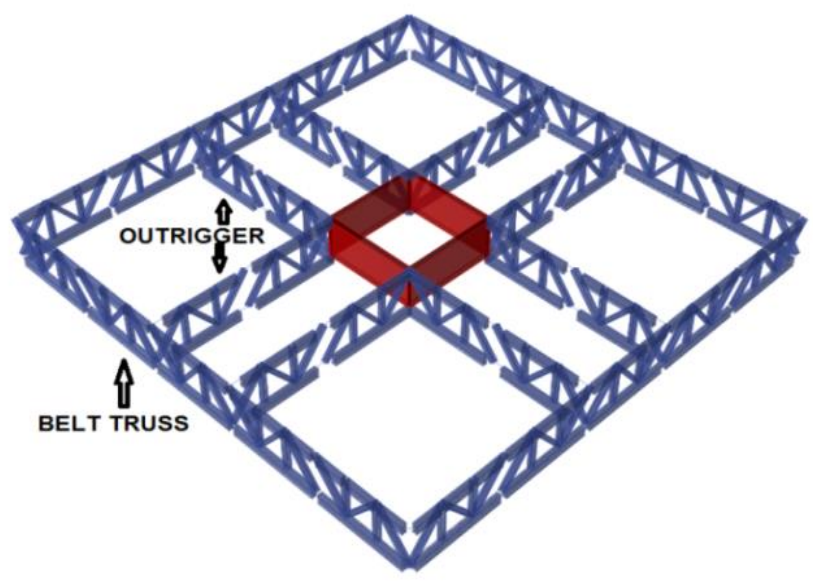

Figure 1. Outrigger with belt truss

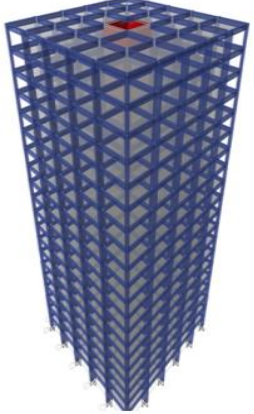

(a)

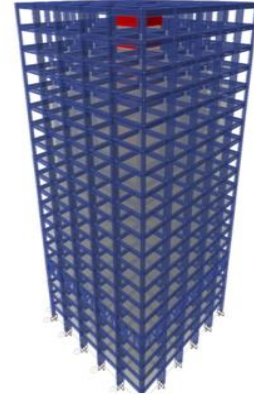

(b)

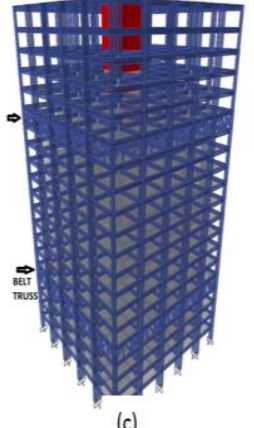

Figure 2. (a) 3D building without outrigger (b) 3D building with single outrigger (c) 3D building with double outrigger

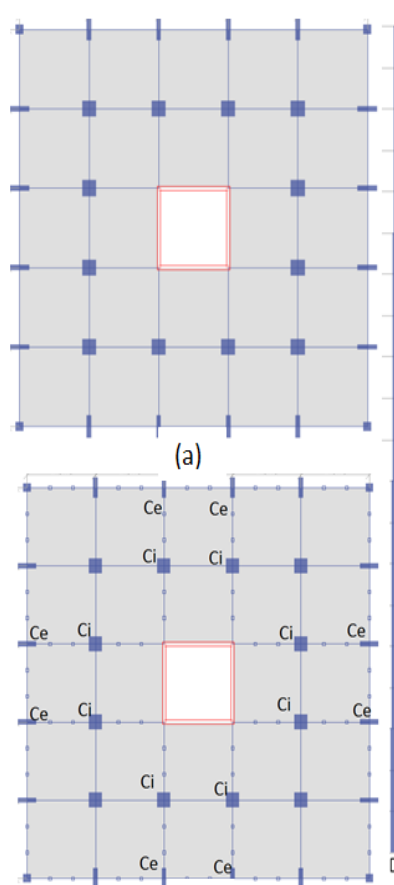

(b)

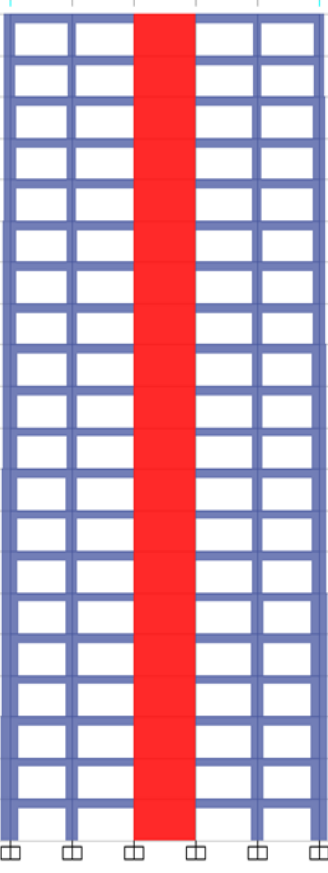

(c)
Story20

Story 19

Story 18

Story 17

Story 16

Story 15

Story 14

Story 13

Story 12

Story11

Story10

Story9

Story8

Story7

Story6

Story5

Story 4

Story3

Story2

Story1

Base

Figure 3. (a) Typical plan without outrigger (b) Typical plan with outrigger and belt truss (c) Typical elevation

\section{B. Building Model}

Three dimensional of the twenty story residential RC building models of 20-story were analyzed as beam-column with core system for resisting lateral loads. For the purpose of modeling the real behavior of the slabs, they were modeled using shell elements to ensure providing stiffness in all directions and transfer mass of the slab to columns and beams. The core has been modeled as shell element. Beams, columns and outriggers were modeled as frame elements. A rigid diaphragm was assumed at all floor levels. The ETABS structure package software has been used to develop the three-dimensional models and performing the dynamic response spectrum analysis following the Egyptian Code for loads as well. In order to account for the modal damping effect, the complete quadratic combination (CQC) technique, which takes into account the statistical coupling between closely spaced modes caused by modal damping

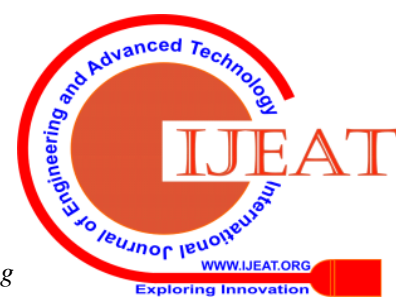


The Seismic zone was III with associated soil type (C), important factor (1) and Reduction factor (5). To determine the optimal locations of outriggers and optimal design method for minimizing the volume of the primary structural members (core wall, outrigger, and external columns) with the goal of efficiently controlling the lateral displacement of a high-rise building, a total of nineteen RC building models were developed in this study as (i) one model with core only (ii) five models with a single outrigger and belt truss at different levels of the building (iii) five models with a single outrigger and without belt truss at different levels of the building (iv) finally eight models with double outrigger and belt truss at different levels of the building as indicated in table. (1)

Table (1): Details of studied specimens

\begin{tabular}{|c|c|c|c|c|}
\hline Model & Symbol & No of outriggers & $\begin{array}{l}\text { Outrigger } \\
\text { location }\end{array}$ & $\begin{array}{l}\text { Outrigger } \\
\text { floor }\end{array}$ \\
\hline 1 & $\mathrm{C}$ & Without & Without & Without \\
\hline 2,3 & C-OT & $\begin{array}{c}\text { One outrigger } \\
\text { with and without } \\
\text { belt truss }\end{array}$ & Top & 20 \\
\hline 4,5 & $\begin{array}{l}\mathrm{C}-\mathrm{O} \\
(2 / 3) \mathrm{h}\end{array}$ & $\begin{array}{c}\text { One outrigger } \\
\text { with and without } \\
\text { belt truss }\end{array}$ & (2/3) height & 14 \\
\hline 6,7 & $\begin{array}{l}\mathrm{C}-\mathrm{O} \\
(1 / 2) \mathrm{h}\end{array}$ & $\begin{array}{c}\text { One outrigger } \\
\text { with and without } \\
\text { belt truss }\end{array}$ & (1/2) height & 10 \\
\hline 8,9 & $\begin{array}{l}\mathrm{C}-\mathrm{O} \\
(1 / 3) \mathrm{h}\end{array}$ & $\begin{array}{c}\text { One outrigger } \\
\text { with and without } \\
\text { belt truss }\end{array}$ & (1/3) height & 7 \\
\hline 10,11 & $\begin{array}{l}\mathrm{C}-\mathrm{O} \\
(1 / 4) \mathrm{h}\end{array}$ & $\begin{array}{c}\text { One outrigger } \\
\text { with and without } \\
\text { belt truss }\end{array}$ & (1/4) height & 5 \\
\hline 12 & $\begin{array}{c}\mathrm{C}-\mathrm{O} \\
(\mathrm{T}-(3 / 4) \mathrm{h})\end{array}$ & $\begin{array}{l}\text { Two outriggers } \\
\text { with belt truss }\end{array}$ & $\begin{array}{c}\text { Top and } \\
\text { (3/4) height }\end{array}$ & $\begin{array}{c}20 \\
\text { and } 15\end{array}$ \\
\hline 13 & $\begin{array}{c}\mathrm{C}-\mathrm{O} \\
(\mathrm{T}-(2 / 3) \mathrm{h})\end{array}$ & $\begin{array}{l}\text { Two outriggers } \\
\text { with belt truss }\end{array}$ & $\begin{array}{l}\text { Top and } \\
(2 / 3) \text { height }\end{array}$ & $\begin{array}{c}20 \\
\text { and } 14\end{array}$ \\
\hline 14 & $\begin{array}{c}\mathrm{C}-\mathrm{O} \\
(\mathrm{T}-(1 / 2) \mathrm{h})\end{array}$ & $\begin{array}{l}\text { Two outriggers } \\
\text { with belt truss }\end{array}$ & $\begin{array}{c}\text { Top and } \\
(1 / 2) \text { height }\end{array}$ & $\begin{array}{c}20 \\
\text { and } 10\end{array}$ \\
\hline 15 & $\begin{array}{c}\mathrm{C}-\mathrm{O} \\
(\mathrm{T}-(1 / 3) \mathrm{h}) \\
\end{array}$ & $\begin{array}{l}\text { Two outriggers } \\
\text { with belt truss }\end{array}$ & $\begin{array}{c}\text { Top and } \\
\text { (1/3) height }\end{array}$ & $\begin{array}{c}20 \\
\text { and } 7\end{array}$ \\
\hline 16 & $\begin{array}{c}\mathrm{C}-\mathrm{O} \\
(\mathrm{T}-(1 / 4) \mathrm{h})\end{array}$ & $\begin{array}{l}\text { Two outriggers } \\
\text { with belt truss }\end{array}$ & $\begin{array}{c}\text { Top and } \\
(1 / 4) \text { height }\end{array}$ & $\begin{array}{c}20 \\
\text { and } 5\end{array}$ \\
\hline 17 & $\begin{array}{c}\mathrm{C}-\mathrm{O} \\
((1 / 4)-(1 / 2) \mathrm{h}) \\
\end{array}$ & $\begin{array}{l}\text { Two outriggers } \\
\text { with belt truss }\end{array}$ & $\begin{array}{c}\text { (1/4)and } \\
(1 / 2) \text { height }\end{array}$ & $\begin{array}{c}5 \\
\text { and } 10 \\
\end{array}$ \\
\hline 18 & $\begin{array}{c}\text { C-O } \\
((1 / 4)-(3 / 4) h)\end{array}$ & $\begin{array}{l}\text { Two outriggers } \\
\text { with belt truss }\end{array}$ & $\begin{array}{c}\text { (1/4)and } \\
\text { (3/4) height }\end{array}$ & $\begin{array}{c}5 \\
\text { and } 15\end{array}$ \\
\hline 19 & $\begin{array}{c}\mathrm{C}-\mathrm{O} \\
((1 / 3)-(2 / 3) \mathrm{h})\end{array}$ & $\begin{array}{l}\text { Two outriggers } \\
\text { with belt truss }\end{array}$ & $\begin{array}{c}\text { (1/3)and } \\
\text { (2/3) height }\end{array}$ & $\begin{array}{c}7 \\
\text { and } 14\end{array}$ \\
\hline
\end{tabular}

$\mathbf{C} \rightarrow$ Core. $\quad \mathbf{O} \rightarrow$ Outrigger. $\quad \mathbf{T} \rightarrow$ Top storey.

(i)h $\rightarrow$ Height ratio

\section{NUMERICAL RESULTS AND DISCUSSION}

Large numbers of simulations involving the studied building were performed under seismic load following the ECP. The models were analyzed in four different cases:

- Building with core only.

- Building with a single outrigger with belt truss located a quarter, one-third, middle, two-third and top of the building

- Building with a single outrigger without belt truss at quarter, one-third, middle, two-third and top of building

- $\quad$ Building with double outrigger with belt truss at top of building in additional to quarter, one-third, middle, two-third and third- quarter of building and also at quarter and middle, quarter and

third- quarter finally at one-third and two-third

The seismic loads produced by the structural package ETABS correspond to ECP with peak ground

accelerations of $0.15 \mathrm{~g}$. Storey moment, which is considered as the most useful responses used for earthquake resistant design strategy are obtained along the height of the building models and presented in a comparative way for all the developed models. The main results obtained from the series of numerical analyses carried out will be summarized in the following. In particular, the responses of all building models under this study will be compared and used to describe and discuss the behavior of their lateral-force resisting systems, when subjected to earthquake-induced demand. Storey displacements which are a measure of the building deflection are also presented following the same manner. The predicted storey drifts which can be defined as the measured displacement between two consecutive stories normalized by storey height are presented for all the developed models with and without outrigger. The results obtained from the analysis are compared and discussed as follows.

\section{A. Displacement}

The variation of lateral displacement in the case of using a single outrigger located at quarter, one-third, middle, two-third and top of the building is presented in Fig. 4 (a). As it can be seen from the Figure, a significant decrease in the obtained displacement has been found using outrigger system with belt truss compared with the case of using only a core system. It is observed that, there is a sudden change in the obtained displacement at the outrigger locations. This can be due to the rotations of the partially restrained core at these points by outrigger-column interaction. The plotted curves clearly indicate that the use of outrigger system at the mid-height provide the highest decreases in the obtained peak displacement compared with the other locations of the outriggers, where the displacement has been reduced by about $31 \%$. On the other hand, locating the outrigger system at the top produces the lowest decrease in the obtained peak displacement of about $17 \%$.

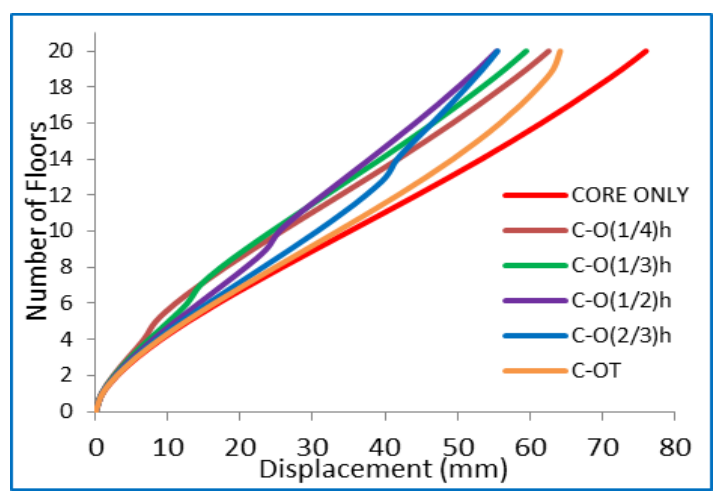

a) All floors displacements 


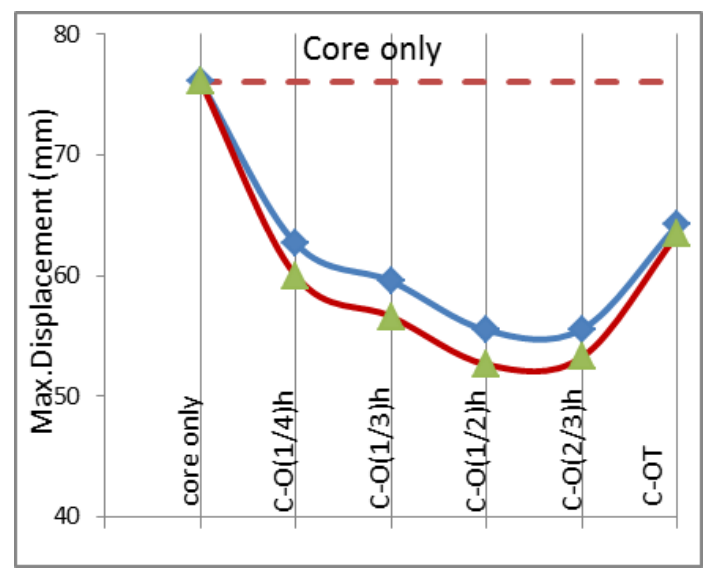

b) Top floor peak displacements

Figure 4: Lateral displacement of building with and without single outrigger and belt truss at different locations due to earthquake loads

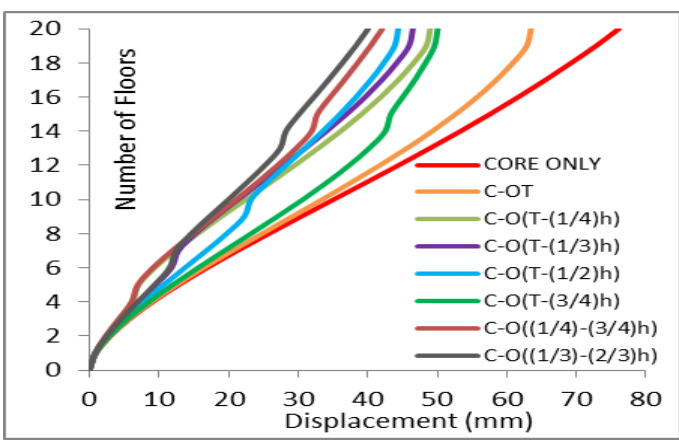

a) All floors displacements

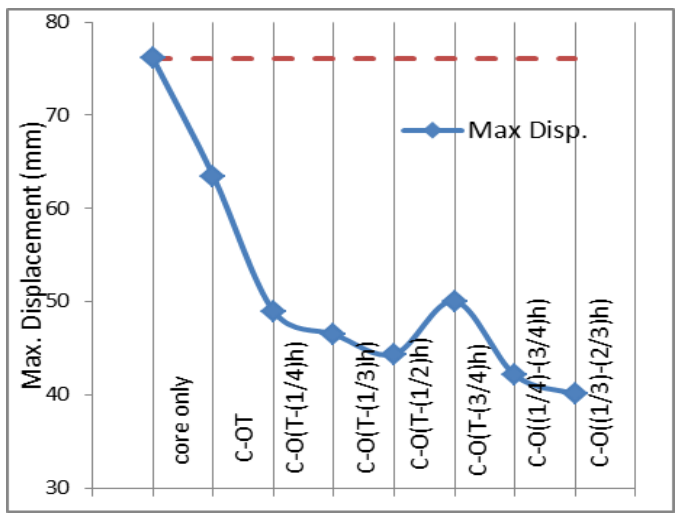

b) Top floor peak displacements

Fig. 5: Lateral displacement of building with and without double outriggers and belt truss at different locations due to earthquake loads

In order to clarify the role of using a belt truss together with the outrigger system, simulation analysis for the building model with and without belt truss has been carried out. The obtained peak displacements for the building with a single outrigger with and without belt truss are shown in Fig.4 (b). The obtained peak values in the case of outrigger system without a belt truss are 62.6, 59.5, 55.5, 55.5, and $63.3 \mathrm{~mm}$ for the outrigger system located at the quarter, one-third, middle, two-third and top of building respectively. The corresponding peak values in the case of using a belt truss are $60.0,56.6,52.6,53.2$, and $63.4 \mathrm{~mm}$. From the

captured displacement values, one can see that the use of a belt truss slightly affects the induced peak displacement for all the considered different locations of the outrigger system. The induced displacement responses also clarify that the optimum location of the single outrigger is at the mid height of the building with or without a belt truss.

Lateral displacement variation versus floor numbers in the case of using double outriggers in which the first outrigger is located at the top floor and the second is varying among the quarter, one-third, middle and three quarters of the height with belt truss is presented in Fig. 5 (a). In additional, the results of the second scenario in which the double outriggers are located at one-third and two-third of the height with belt truss are also presented. Moreover, the simulation results for the third scenario where the double outriggers are located at quarter and three quarters of the height with belt truss are plotted in the same figure. The captured displacement at the top of the building is reduced by about $48 \%$ and $45 \%$ for the second and third scenarios respectively. For the first scenario the percentage reduction values are $42 \%$ for the outriggers at the top and middle of the height and 38\% for on top and two-third of the height as presented in Fig. 5 (b). From the obtained results, the second scenario provides the optimal locations of the double outriggers according to displacement control criteria.

\section{B. Storey Drift}

Results of maximum story drift patterns of the 20-storey high-rise building model with single and double outrigger system with belt truss at different levels under seismic load following the ECP are presented in Fig. 6. The obtained results demonstrate the differences between the drift profiles of the building structure modeled with core only to resist lateral loads and other models with outrigger system at different levels. As it can be seen from the figure, the building model with core only has drift ratios of higher values than those associated with the considered outrigger system. The building models with outrigger system have sudden decrease in the obtained drift values at the specified outrigger levels. This observed trend has been noticed for all the considered outrigger system models.

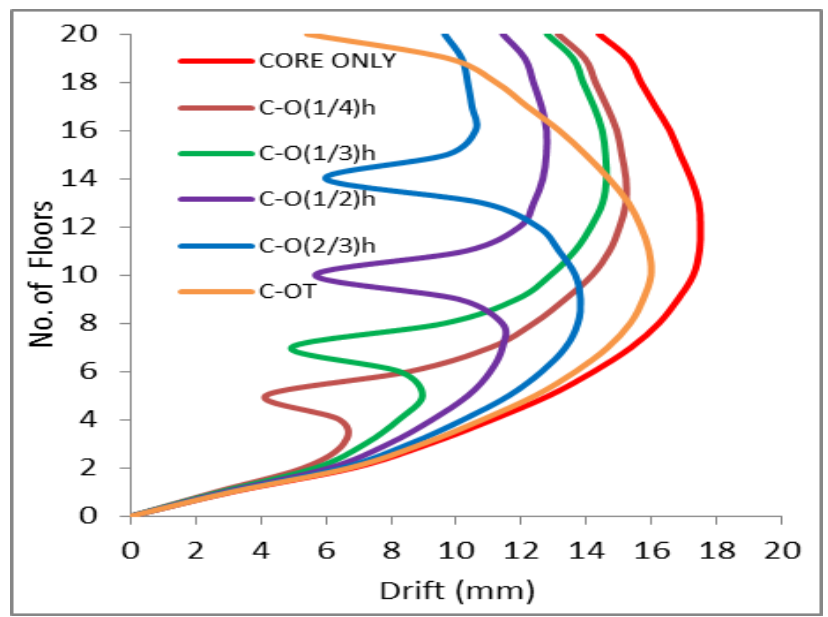

a)Single outrigger 


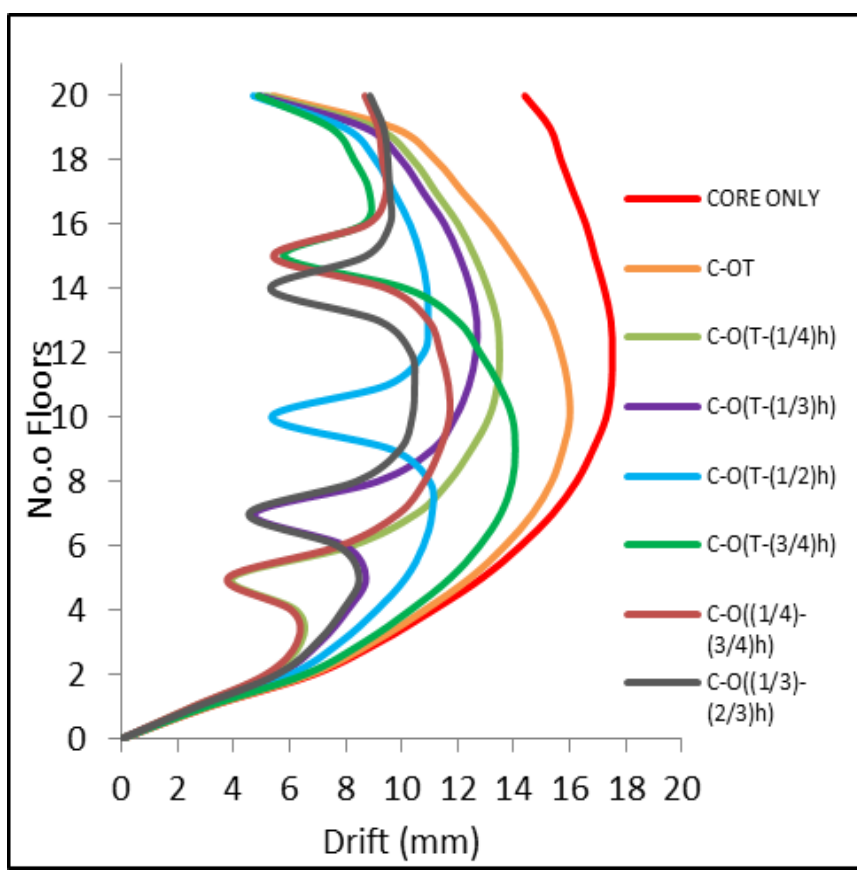

b) Double outrigger

Fig.6: Storey drift of Building with and without outriggers and belt truss due to Earthquake Loads

\section{Overturning Moment}

Variations in the obtained peak storey moments seem to be insignificant and show a slight change with the variation of the outrigger system level as shown in Fig. 7. As it can be seen from the figure, the achieved reduction values in the base moment has been found to be about $4 \%$ associated with the use of outrigger at the quarter height compared with the case of core only.

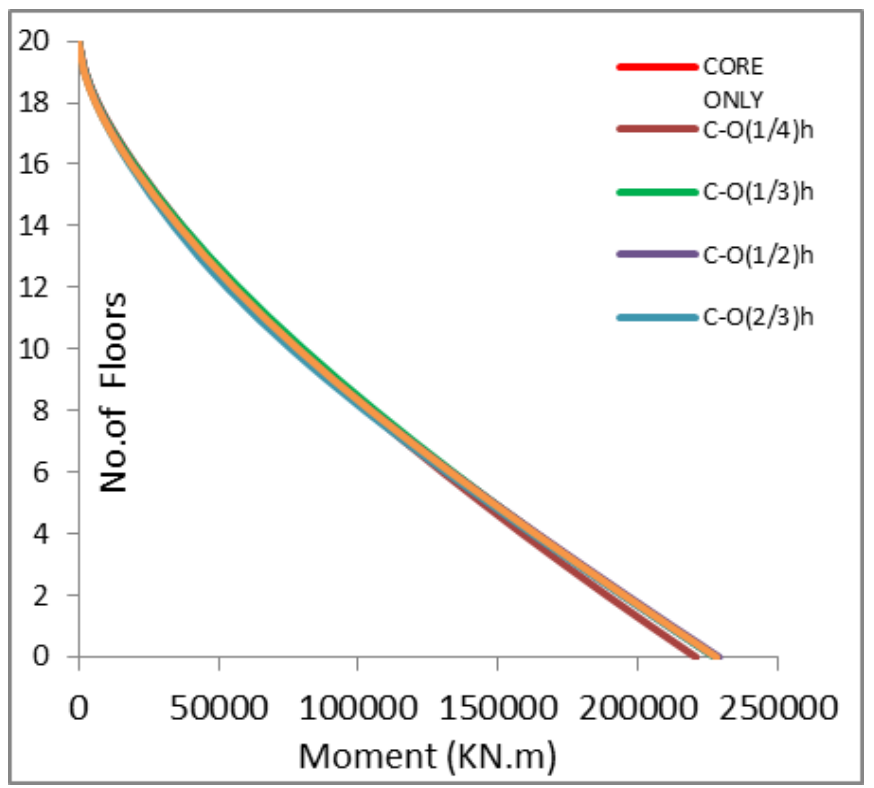

a)Single outrigger

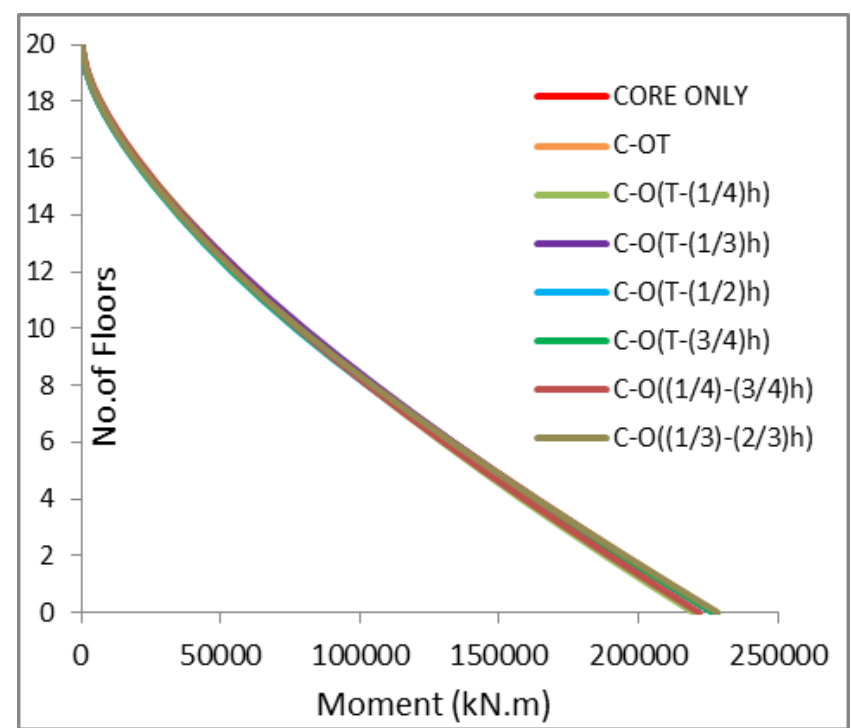

b) Double outrigger

Fig. 7: Overturning moment of building with and without outrigger and belt truss due to earthquake loads

\section{Core Moment}

Values of maximum moments on the core due to the applied earthquake loads are shown in the Fig.8 for the considered building models with and without single and double outriggers. The obtained peak moment values on the core have been found to vary significantly according to the outrigger locations. Reduced values of 36\%, $28 \%, 17 \%$, 9\% and $3 \%$ of the induced core moment have been obtained for single outrigger at quarter, one-third, middle, two-third and top respectively. On the other hand, the third scenario of the double outrigger case provides the height reduction ratio of $34.5 \%$ of the induced core moments. While the first scenario in which the double outrigger system are located at the top and quarter height reduces the induced core moment by a ratio of 33\%. These reduction values confirm that the use of a single outrigger system at quarter height and the third scenario of using double outriggers is the most beneficial in reducing core moments and providing an economical design

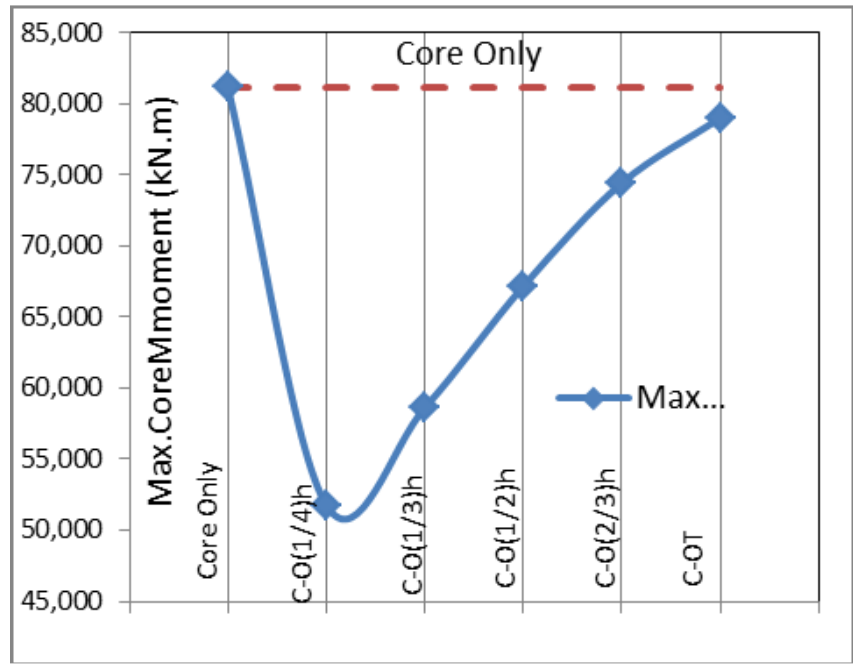

a)Single outrigger

Published By:

Retrieval Number: C5137029320/2020@BEIESP DOI: 10.35940/ijeat.C5137.029320 Journal Website: www.ijeat.org 


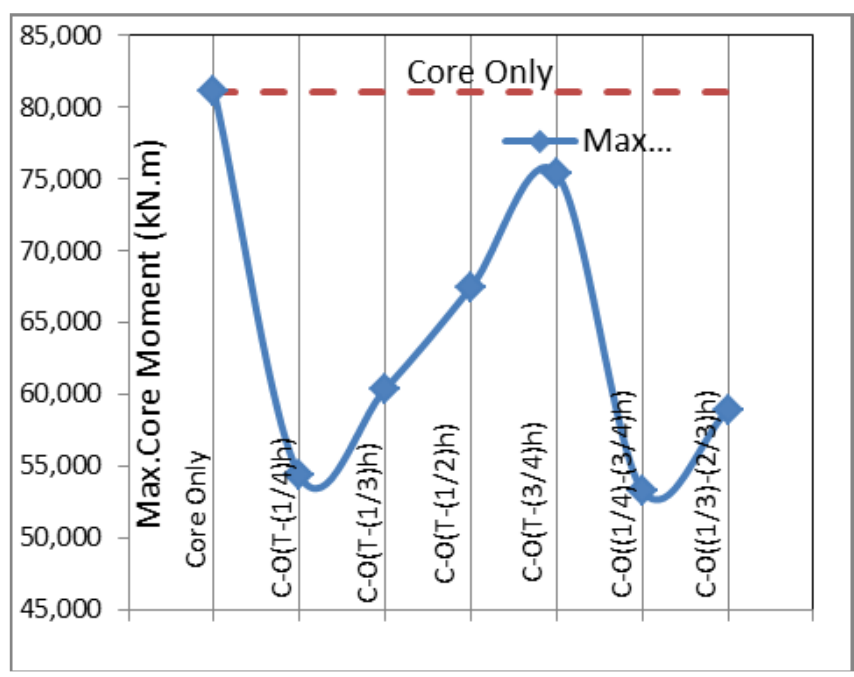

b) Double outrigger

Fig. 8: variation of maximum moments on the core with and without outrigger and belt truss due to earthquake loads

\section{E. Columns moments}

The induced moments on the interior and exterior columns (Ci and Ce), (see Fig. 3 (a)) connected to the core through outriggers located at different levels are presented in Fig. 9. The obtained column moment results demonstrate reduced values by about $15 \%, 11 \%, 6 \%, 3 \%$ and $1 \%$ for the use of single outrigger at quarter, one-third, middle, two-third and top respectively. However, the third scenario of the double outrigger case produces the height reduction ratio of $16 \%$ of the induced column moments. The use of the double outrigger system on top and quarter height provides reduction ratio almost of $15 \%$ of the induced column moments. These reduction values indicated that the optimum locations of outrigger system for column design are at quarter height for a single outrigger system and the third scenario of using double outriggers

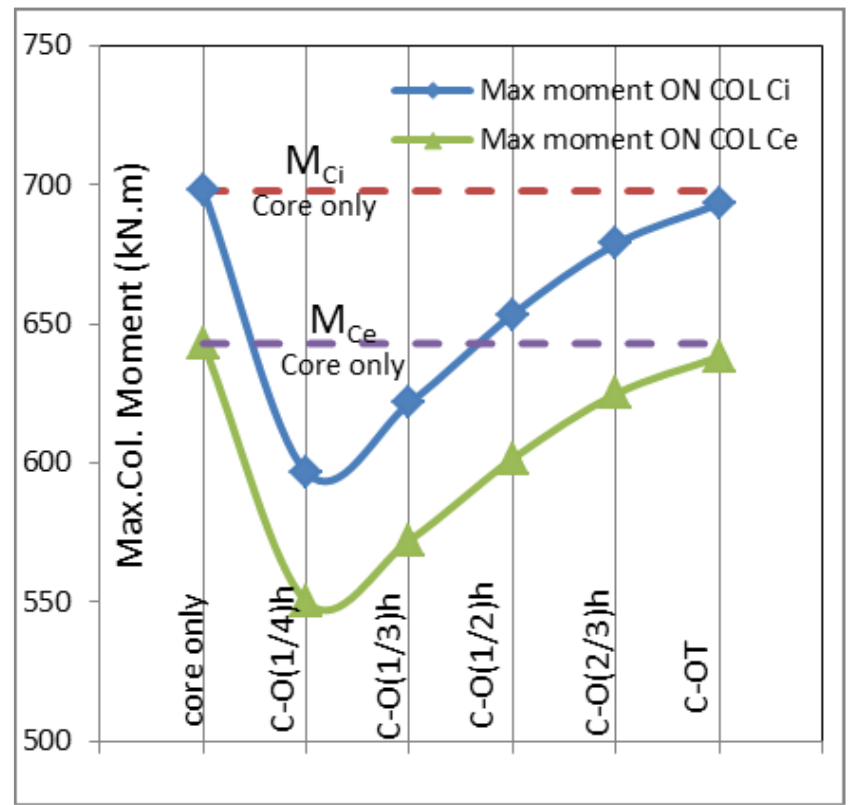

a)Single outrigger

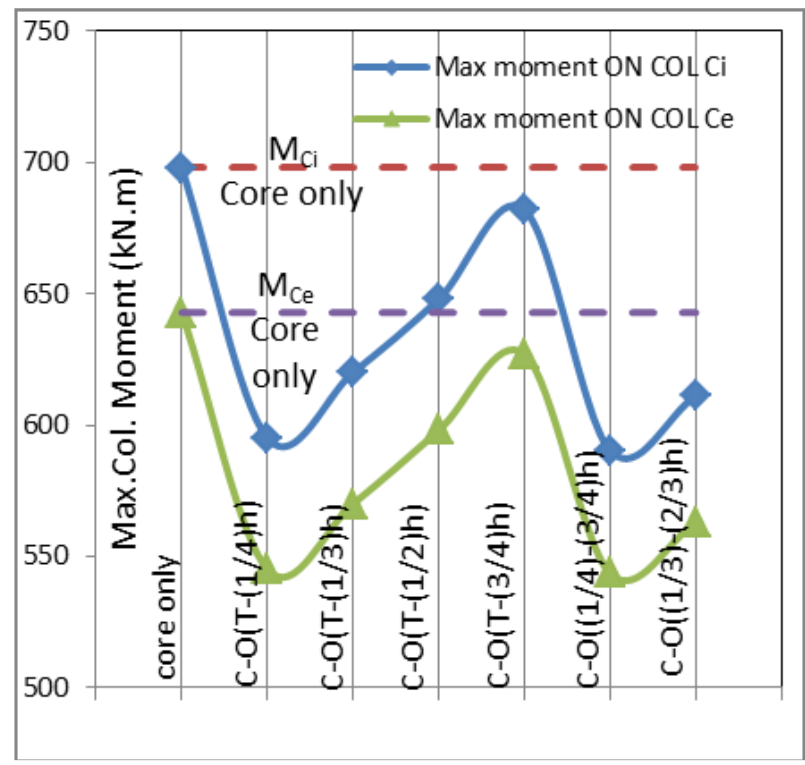

b) Double outrigger

Fig. 9: variation of maximum moments on the (Ci) and (Ce) with and without outrigger and belt truss due to earthquake loads

\section{CONCLUSION}

The current research study has been carried out on RC tall buildings with central core wall having an outrigger system under seismic loads by a series of dynamic response spectrum (RS). The effect of variation of outrigger level and the number has been studied as well. The following results summarize the main findings of the considered different scenarios of the structural models.

1- The outrigger structural system has a significant influence on the global performance of the building structure, where it increases the stiffness and makes the structural configuration more efficient under lateral loads.

2- The outrigger system not only reduced the induced storey displacements, but also minimized the inter storey drifts ratios as well as the core internal stresses compared to the building with core only.

3- Use of a belt truss with outrigger slightly reduced the induced peak storey displacement for all the considered different locations of the outrigger system.

4- Compared to the building with core only model, the models with outrigger system have sudden decrease in the obtained responses at the specified outrigger levels.

5- The level of outrigger has a significant role on the obtained response values under the seismic loads.

6- The use of a single outrigger at only top of the building is not beneficial in reducing building responses as compared to the other cases of different outrigger locations.

7- Regardless the location, the use of double outrigger system reduces the induced response values as compared to the case of using a single outrigger system. 
8- Form storey displacements point of view, the optimum locations of outriggers are the mid height of the building in case of using single outrigger and the second scenario in case of using double outrigger in which the outriggers are located at one-third and two-third of the height.

9- The optimum locations of outriggers are quarter height of the building in case of using single outrigger and the third scenario in case of using double outrigger in whi [ the outriggers are located at quarter and three quarters of the building in order to minimize the induced moment values on the core and columns.

10- The optimum location of the double outrigger is the first scenario, in which the first outrigger is located at the top floor and the second at the mid height of the building, according to displacement control criteria or at quarter height of the building, inorder to minimize the maximum moment on the core and columns.

\section{REFERENCES}

1. K. Kamath, N. Divya, and A.U. Rao, "A Study On Static And Dynamic Behavior Of Outrigger Structural System For Tall Buildings," Bonfring International Journal of Industrial Engineering and Management Science, vol. 2, no. 4, pp. 15-20, 2012. DOI: 10.9756/BIJIEMS.1655

2. R.K. Nanduri, B. Suresh, and I. Hussain, "Optimum Position of Outrigger System for High-Rise Reinforced Concrete Buildings under Wind and Earthquake Loadings," American Journal of Engineering Research (AJER), vol. 2, no. 8, pp. 76-89, 2013.

3. M.R. Suresh, and S. Badami, "A Study on Behavior of Structural Systems for Tall Buildings Subjected to Lateral Loads," International Journal of Engineering Research and Technology, vol. 3, no. 7, pp. 989-994,2014.

4. A. Mulla, and B.N Srinivas, "A Study on Outrigger System in A Tall R.C Structure With Steel Bracing," International Journal of Engineering Research \& Technology (IJERT), vol. 4, no. 7, pp. 551-557,2015

5. D.J. Prasad, and S. Kumar, "Comparison Of Seismic Performance Of Outrigger And Belt Truss System In A RCC Building With Vertical Irregularity," International Journal of Research in Engineering and Technology, vol. 5, no. 20, pp. 125-132,2016

6. K. Venkatesh, and B. Ajitha,. Behavior of a Building with Outrigger System. Paper presented at the $6^{\text {th }}$ International Conference on Recent Development in Engineering Science, Humanities and Management, Chandigarh, India, pp.14-25, 2017.

7. C. Patel, and K. Kuldeep, "The Study on Behaviour of Outriggers for Tall Buildings Subjected to Lateral Load," International Research Journal of Engineering and Technology, vol. 4, no 7, pp. 3239-3245, 2017.

8. V. Dongre, and V. Garg, "Analyzing Utility of Component Elements of Outrigger System," International Research Journal of Engineering and Technology (IRJET), vol. 5, no. 1, pp. 1141-1145, 2018

9. Housing and Building National Research Centre, Ministry of Housing, Utilities and Urban Planning. (2012). Egyptian code for calculating loads and forces in structural work and masonry (ECP-201).

10. S.B Sukhdeve1," Optimum Position of Outrigger in G+40 RC Building," International Journal of Science Technology \& Engineering, vol. 2, no. 10, pp. 1051-1055, 2016

\section{AUTHORS PROFILE}

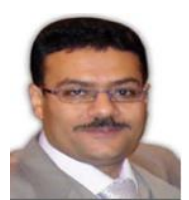

Waleed Abdallah Ali, is Assistant Professor in the Faculty of Engineering, Civil Department, Helwan University, Cairo, Egypt, where he has been a faculty member since 1997. He has about 20 years teaching experience for undergraduate students. He supervised many undergraduate projects and several master theses. He also supervised PHD students in Helwan University. His PHD studied "Behavior of Strengthened Reinforced Concrete Slabs in Fires" in March. 2008. His research interests lie in the area of structure analysis, reinforced concrete and Earthquake analysis. He has collaborated actively with researchers in other disciplines of civil engineering. He has attended

in

International Conference on FRP Composites in Civil Engineering 2014

Vancouver, Canada | August 20-22, 2014 and the 8th International
Conference on Fiber Reinforced Polymer (FRP) Composites in Civil Engineering (CICE2016), 14-16 December 2016, Hong Kong, China
Published By:

1483 Blue Eyes Intelligence Engineering \& Sciences Publication 